\title{
Patient Navigation Models for Lung Cancer
}
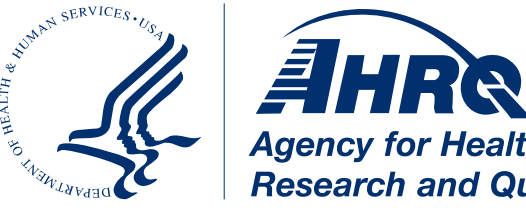

Agency for Healthcare Research and Quality
Effective Health

Care Program 


\title{
Rapid Evidence Product
}

\section{Patient Navigation Models for Lung Cancer}

\author{
Prepared for: \\ Agency for Healthcare Research and Quality \\ U.S. Department of Health and Human Services \\ 5600 Fishers Lane \\ Rockville, MD 20857 \\ www.ahrq.gov
}

Contract No. 290-2017-00003-C

Prepared by:

Scientific Resource Center

Portland, OR

\section{Investigators:}

Jennifer Gilbert, M.D., M.P.H.

Stephanie Veazie, M.P.H.

Kevin Joines, B.S.

Kara Winchell, M.A.

Rose Relevo, M.L.I.S.

Robin Paynter, M.L.I.S.

Jeanne-Marie Guise, M.D., M.P.H.

AHRQ Publication No. 18(19)-EHC028-EF

December 2018 
This report is based on research conducted by the Scientific Resource Center under contract to the Agency for Healthcare Research and Quality (AHRQ), Rockville, MD (Contract No. 2902017-00003-C). The findings and conclusions in this document are those of the authors, who are responsible for its contents; the findings and conclusions do not necessarily represent the views of AHRQ. Therefore, no statement in this report should be construed as an official position of AHRQ or of the U.S. Department of Health and Human Services.

\section{None of the investigators have any affiliations or financial involvement that conflicts with the material presented in this report.}

The information in this report is intended to help health care decisionmakers - patients and clinicians, health system leaders, and policymakers, among others-make well-informed decisions and thereby improve the quality of health care services. This report is not intended to be a substitute for the application of clinical judgment. Anyone who makes decisions concerning the provision of clinical care should consider this report in the same way as any medical reference and in conjunction with all other pertinent information, i.e., in the context of available resources and circumstances presented by individual patients.

This report is made available to the public under the terms of a licensing agreement between the author and the Agency for Healthcare Research and Quality. This report may be used and reprinted without permission except those copyrighted materials that are clearly noted in the report. Further reproduction of those copyrighted materials is prohibited without the express permission of copyright holders.

AHRQ or U.S. Department of Health and Human Services endorsement of any derivative products that may be developed from this report, such as clinical practice guidelines, other quality enhancement tools, or reimbursement or coverage policies, may not be stated or implied.

Persons using assistive technology may not be able to fully access information in this report. For assistance contact epc@ahrq.hhs.gov.

Suggested citation: Gilbert J, Veazie S, Joines K, Winchell K, Relevo R, Paynter R, Guise J-M. Patient Navigation Models for Lung Cancer. Rapid Evidence Product. (Prepared by Scientific Resource Center under Contract No. 290-2017-00003-C.) AHRQ Publication No. 18(19)EHC028-EF. Rockville, MD: Agency for Healthcare Research and Quality; December 2018. Posted final reports are located on the Effective Health Care Program search page.

DOI: https://doi.org/10.23970/AHRQEPCRAPIDLUNG. 


\section{Preface}

Recognized for excellence in conducting comprehensive systematic reviews, the Agency for Healthcare Research and Quality (AHRQ) Evidence-based Practice Center (EPC) Program is expanding its portfolio to include Rapid Evidence Products. The program has begun to develop a range of Rapid Evidence Products to assist end-users in making specific decisions in a limited timeframe. The Scientific Resource Center (SRC) supports the activities of the EPC program, including piloting and producing Rapid Evidence Products.

In 2014, AHRQ EPCs produced a taxonomy of rapid evidence products produced by leading organizations around the world. ${ }^{\text {a-c }}$ This taxonomy now informs the development of Rapid Evidence Products. Based on level of synthesis, the report classified products as inventories, rapid responses, and rapid reviews. On one end of the spectrum, evidence inventories offer an assessment of the quantity and type of evidence without presenting results. On the other end, rapid reviews adapt and streamline traditional systematic review methods to provide a limited evidence synthesis.

To shorten timelines, reviewers must make strategic choices about which processes to abridge. Common adaptations to provide rapid evidence include: narrowly focusing questions, limiting the number of databases searched and/or modifying search strategies, using a single reviewer and/or abstractor with a second to provide verification, and restricting to studies published in the English language. However, the adaptations made for expediency may limit the certainty and generalizability of the findings from the review, particularly in areas with a large literature base. Transparent reporting of the methods used, the resulting limitations of the evidence synthesis, and the strength of evidence of included studies are extremely important. While tradeoffs will likely differ for each topic, they are described so readers can adjudicate the limitations of the findings and conclusions of the review.

While rapid evidence products are often sufficient for decisionmaking on their own, at other times they can uncover a large complex literature base that encourages end-users to seek a full review. Even in this instance, the rapid evidence review can provide a map of the evidence and assist decisionmakers in targeting resources to areas of highest interest and greatest potential value.

AHRQ expects that these rapid evidence products will be helpful to health plans, providers, purchasers, government programs, and the health care system as a whole. Transparency and stakeholder input are essential to the Effective Health Care Program.

If you have comments on this report, they may be sent by mail to the Task Order Officer named below at: Agency for Healthcare Research and Quality, 5600 Fishers Lane, Rockville, MD 20857, or by email to epc@ahrq.hhs.gov.

iii

a. Hartling L, Guise J-M, Hempel S, et al. EPC methods: AHRQ End-user perspectives of rapid reviews. Rockville (MD): 2016. https://www.ncbi.nlm.nih.gov/pubmed/27195347

b. Hartling L, Guise J-M, Kato E, et al. EPC Methods: An Exploration of Methods and Context for the Production of Rapid Reviews. Rockville (MD): 2015. https://www.ncbi.nlm.nih.gov/pubmed/25654160

c. Hartling L, Guise J-M, Hempel S, et al. Fit for purpose: perspectives on rapid reviews from end-user interviews. Systematic Reviews.

2017;6:32. doi: 10.1186/s13643-017-0425-7. PMID: PMC5316162. 
Gopal Khanna M.B.A.

Director

Agency for Healthcare Research and Quality

Stephanie Chang, M.D., M.P.H.

Director

Evidence-based Practice Center Program

Center for Evidence and Practice

Improvement

Agency for Healthcare Research and Quality
Arlene S. Bierman, M.D., M.S.

Director

Center for Evidence and Practice Improvement

Agency for Healthcare Research and Quality

Christine Chang, M.D., M.P.H.

Task Order Officer

Center for Evidence and Practice

Improvement

Agency for Healthcare Research and Quality 


\section{Acknowledgments}

The authors gratefully acknowledge the following individuals for their contributions to this project: Martha Gerrity and Mark Helfand. 


\section{Patient Navigation Models for Lung Cancer}

\section{Structured Abstract}

Background. Multiple patient navigation programs have been developed to address barriers to care (e.g., financial, logistical, and communication) across the cancer care continuum, but health systems are unsure which components of patient navigation are important and how to implement them. In addition the effectiveness of patient navigation programs to improve lung cancer outcomes is uncertain.

Purpose. To review recent literature on components of patient navigation programs addressing all types of cancer, the effectiveness of patient navigation programs on lung cancer outcomes, and the variable effectiveness of patient navigation programs on lung cancer outcomes based on patient characteristics. This report was developed to address the diverse research needs of a stakeholder group interested in the needs of people with lung cancer.

Methods. We searched for systematic reviews from 2015 to 2018 in PubMed $^{\circledR}$, CINAHL ${ }^{\circledR}$, Cochrane Database of Systematic Reviews, Veterans Affairs Evidence-based Synthesis Program, Agency for Healthcare Research and Quality Effective Health Care Program, PubMed Health, and PROSPERO. We also searched for primary studies from 2013 to 2018 in PubMed and CINAHL. We extracted data from systematic reviews and primary studies, and synthesized results.

Findings. We identified four systematic reviews and six primary studies that focused primarily on breast, cervical, prostate, and colorectal cancer. Navigators' backgrounds varied from lay people to health care professionals, and training ranged from a few to several hundred hours. Navigation programs were both individual and team based, were delivered in diverse health care settings, and had more clearly defined entry criteria than exit criteria. Navigators performed multiple diverse services, including assisting patients to overcome health care system barriers, maintaining resource networks, and promotion of patient engagement. Only two completed studies evaluated the effectiveness of lung cancer patient navigation programs. One randomized clinical trial found that navigated patients were more likely to receive a screening chest computed tomography, and one observational study found that navigation was associated with increased satisfaction with care. No completed studies analyzed the effectiveness of lung cancer patient navigation programs based on patient characteristics.

Implications. Patient navigation programs for all cancer types are quite diverse with regard to navigators' characteristics and program structure. Future research studies should describe components in sufficient detail to facilitate implementation and determine which program is most effective for which health system. Lung cancer patients face unique challenges in managing their care, so additional studies on which components are important for lung cancer may be warranted. 


\section{Contents}

Background ............................................................................................................................................ 1

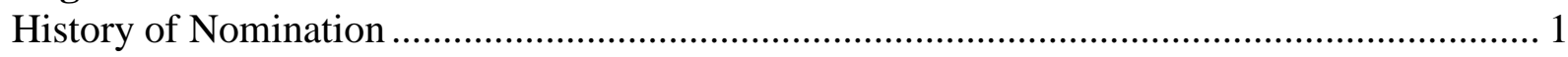

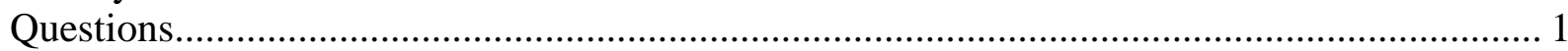

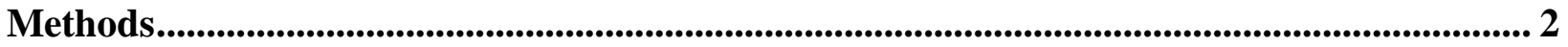

Results ...................................................................................................................................... 3

Question 1. What are the main components of patient navigation interventions for screening, diagnosis, treatment, and surveillance of any type of cancer? .................................................... 3

Systematic Reviews and Primary Studies ............................................................................ 3

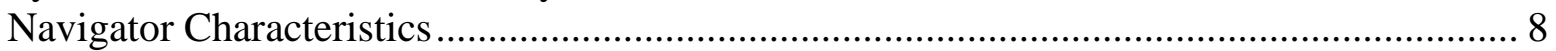

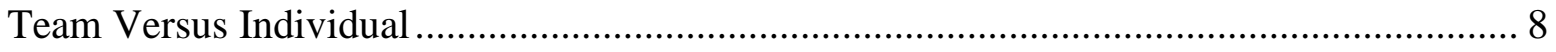

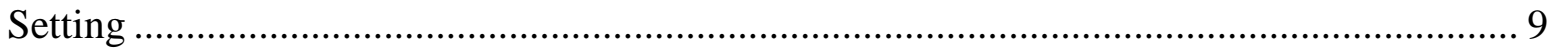

Types of Services Provided......................................................................................... 9

Patient Entry and Exit Criteria ............................................................................................. 10

Question 2. What is the effectiveness of patient navigation interventions for improving lung cancer outcomes across the spectrum of care? ..................................................................... 10

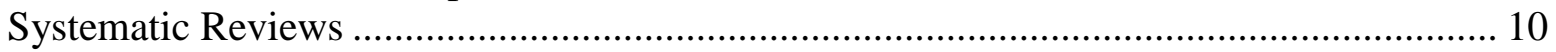

Primary Studies .................................................................................................... 10

Completed Studies ........................................................................................................... 10

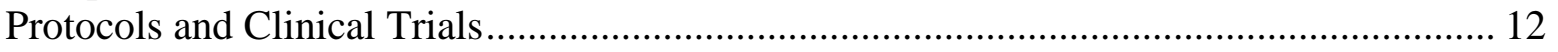

Question 3. Does the effectiveness of patient navigation interventions for improving lung cancer outcomes vary by geographic location (rural, suburban, urban), socioeconomic status,

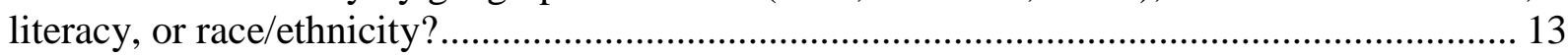

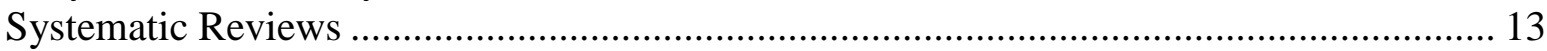

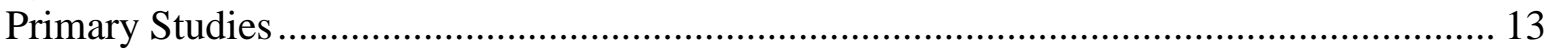

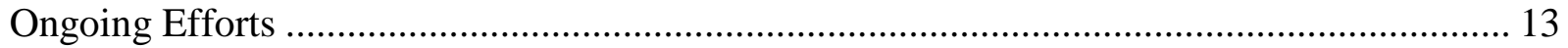

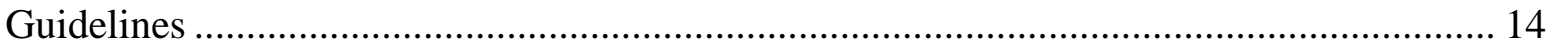

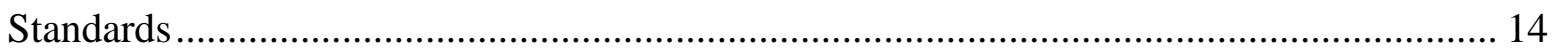

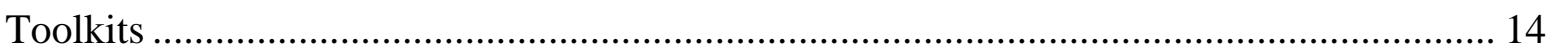

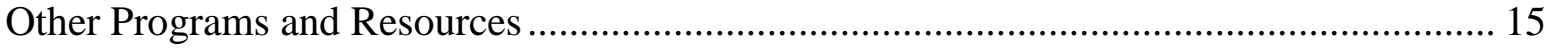

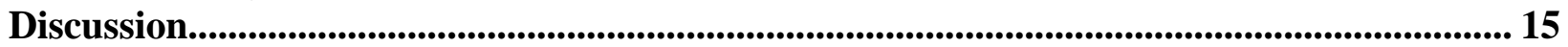

Limitations of Review Methodology .................................................................................. 16

Implications for Future Research ................................................................................. 16

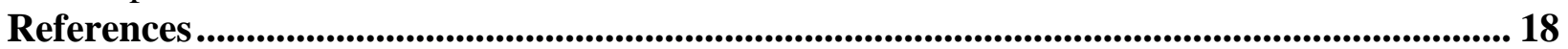

Tables

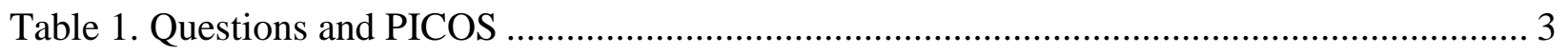

Table 2. Systematic reviews relevant to Question 1 ….................................................................... 5

Table 3. Completed primary studies relevant to Question 2......................................................... 11

Table 4. Protocols and clinical trials relevant to Questions 2 and 3 ........................................... 12

\section{Appendix}

Appendix A. Search Strategies 


\section{Background}

Nearly 1.7 million new diagnoses of cancer are expected in the United States in $2018 .{ }^{4}$ Lung cancer will comprise 13 percent of these diagnoses and accounts for a quarter of cancer-related deaths. ${ }^{4}$ Although considerable progress had been made in the previous 20 years, the most recent 5-year survival rate for lung cancer remains under 20 percent. $^{4}$

Patient navigation models have been adopted due to the complexity of treatment and necessary coordination of medical interventions throughout the continuum of cancer care. Patient navigation began in the United States in 1990 with a surgical oncologist, Harold Freeman, who wanted to address the disparities in breast cancer outcomes among African American women in Harlem. ${ }^{5}$ The primary aims of patient navigation are to eliminate financial, logistic, or communication barriers to the receipt of medical services by providing education and resources to patients. ${ }^{6}$ In 2005 the Patient Navigator and Chronic Disease Prevention Act was signed into law which authorized a demonstration grant program to provide patient navigator services to reduce barriers and improve health care outcomes. ${ }^{7}$ Additional guiding principles of patient navigation include a patient-centric delivery model, clear scope of practice, defined entry and exit criteria for navigation, and having a coordinator for the navigation system. ${ }^{5}$ Patient navigation models have been shown to improve cancer and patient-related outcomes including decreased time between diagnosis and treatment, increased adherence to care, and improved quality of life. ${ }^{6}$

Currently, there is no consensus on which patient navigation models are most effective. These models vary according to a number of factors including education, occupational background, and cultural competence of the individual employed as the patient navigator. A recent position statement by the Oncology Nursing Society states that effective navigation models use a variety of health care and non-health care personnel. ${ }^{6}$ However, there are very few studies directly comparing different models, and evidence has yet to be synthesized regarding relative effectiveness. ${ }^{8}$

\section{History of Nomination}

Patient navigation models for lung cancer was nominated to the Agency for Healthcare Research and Quality (AHRQ) Evidence-based Practice Center program by the Patient Centered Outcomes Research Institute (PCORI)-funded Stakeholder Engagement in question Development (SEED) project, based at Virginia Commonwealth University. The SEED project brought together various stakeholders (patients, providers, and health systems) to identify high priority, patient-important topics for research. The nominator is interested in gaining a better understanding of the main components of patient navigation interventions, as well as whether these interventions positively impact lung cancer outcomes, in order to inform a broad research and policy agenda.

\section{Questions}

The questions for this nomination are:

1. What are the main components of patient navigation interventions for screening, diagnosis, treatment, and surveillance of any type of cancer?

a. Navigator characteristics (background [e.g., Registered Nurse, lay person], training, cultural competence) 
b. Team versus individual

c. Setting (single site versus health system)

d. Types of services delivered

e. Patient entry and exit criteria

2. What is the effectiveness of patient navigation interventions for improving lung cancer outcomes across the spectrum of care?
a. Screening
b. Diagnosis
c. Treatment
d. Surveillance

3. Does the effectiveness of patient navigation interventions for improving lung cancer outcomes vary by geographic location (rural, suburban, urban), socioeconomic status, literacy, or race/ethnicity?

\section{Methods}

We conducted a literature scan and brief evidence synthesis in order to address the needs of our nominator. We first searched for systematic reviews (SRs) in PubMed and the Cumulative Index of Nursing and Allied Health Library (CINAHL) as well as Cochrane Database of Systematic Reviews, Veterans Affairs (VA) Evidence-based Synthesis Program, AHRQ Effective Health Care Program, PubMed Health, and PROSPERO from the past three years. We then searched for primary studies in PubMed and CINAHL from the past five years. We conducted a three-year SR search and a five-year primary study search in order to capture the most relevant and recent literature. Search strategies are available in Appendix A.

For Question 1, we included studies that explicitly described models for patient navigation or described services delivered as part of patient navigation. For Questions 2-3 we included studies that examined the effectiveness of patient navigation for improving lung cancer outcomes. For all questions, we only included quantitative studies.

We also searched for guidelines, grey literature, and clinical trials on patient navigation for cancer care. We spoke to a topic expert on patient navigation and looked at resources recommended by him.

To define the inclusion criteria for the questions, we specify the population, interventions, comparators, outcomes, and setting (PICOS) of interest (Table 1). 
Table 1. Questions and PICOS

\begin{tabular}{|c|c|c|c|}
\hline Questions & $\begin{array}{l}\text { 1. What are the main } \\
\text { components of patient } \\
\text { navigation interventions for } \\
\text { screening, diagnosis, } \\
\text { treatment, and surveillance of } \\
\text { any type of cancer? }\end{array}$ & $\begin{array}{l}\text { 2. What is the effectiveness } \\
\text { of patient navigation } \\
\text { interventions for } \\
\text { improving lung cancer } \\
\text { outcomes across the } \\
\text { spectrum of care? }\end{array}$ & $\begin{array}{l}\text { 3. Does the effectiveness of } \\
\text { patient navigation } \\
\text { interventions for improving } \\
\text { lung cancer outcomes vary } \\
\text { by geographic location } \\
\text { (rural, suburban, urban), } \\
\text { socioeconomic status, } \\
\text { literacy, or race/ethnicity? }\end{array}$ \\
\hline Population & $\begin{array}{l}\text { Adults being screened for, at risk } \\
\text { of, or diagnosed with any type of } \\
\text { cancer }\end{array}$ & $\begin{array}{l}\text { Adults being screened for, at } \\
\text { risk of, or diagnosed with } \\
\text { lung cancer }\end{array}$ & $\begin{array}{l}\text { Adults being screened for, at } \\
\text { risk of, or diagnosed with lung } \\
\text { cancer }\end{array}$ \\
\hline Interventions & $\begin{array}{l}\text { Any patient navigation } \\
\text { intervention }\end{array}$ & $\begin{array}{l}\text { Any patient navigation } \\
\text { intervention }\end{array}$ & $\begin{array}{l}\text { Any patient navigation } \\
\text { intervention }\end{array}$ \\
\hline Comparators & $\mathrm{N} / \mathrm{A}$ & $\begin{array}{l}\text { Any comparator (including } \\
\text { pre-post or separate control } \\
\text { group) }\end{array}$ & $\begin{array}{l}\text { Any comparator (including pre- } \\
\text { post or separate control group) }\end{array}$ \\
\hline Outcomes & N/A & $\begin{array}{l}\text { - Rate of screening } \\
\text { - Time to diagnosis } \\
\text { - Time to treatment } \\
\text { - Symptom management } \\
\text { - Quality of life } \\
\text { - Patient satisfaction } \\
\text { - Mental health (e.g., } \\
\text { - depression, anxiety) } \\
\text { - Survival } \\
\text { - Harms }\end{array}$ & $\begin{array}{l}\text { - Rate of screening } \\
\text { - Time to diagnosis } \\
\text { - Time to treatment } \\
\text { - Symptom management } \\
\text { - Quality of life } \\
\text { - Patient satisfaction } \\
\text { - Mental health (e.g., } \\
\text { - depression, anxiety) } \\
\text { - Survival } \\
\text { - Harms }\end{array}$ \\
\hline Setting & N/A & $\begin{array}{l}\text { Community and health } \\
\text { system }\end{array}$ & Community and health system \\
\hline
\end{tabular}

Abbreviations: N/A=not applicable; PICOS=Population, intervention, comparator, outcome, setting

\section{Results}

Question 1. What are the main components of patient navigation interventions for screening, diagnosis, treatment, and surveillance of any type of cancer?

\section{Systematic Reviews and Primary Studies}

We identified four SRs ${ }^{9-12}$ that examined patient navigation across the cancer care continuum, including screening, ${ }^{9,}{ }^{10}$ diagnosis, ${ }^{11,12}$ and treatment. ${ }^{11,12}$ The main cancer types represented included breast, ${ }^{10-12}$ colorectal, ${ }^{9-12}$ prostate, ${ }^{11}$ and cervical cancer. ${ }^{10,11}$ One SR included patients with a wide range of cancer types (including lung cancer). ${ }^{12}$ Patient navigation programs targeted vulnerable patient groups, including those who are low-income, ${ }^{10}$ medically underserved, ${ }^{11}$ part of racial/ethnic minority groups, ${ }^{9,}{ }^{10}$ or older. ${ }^{12}$ Table 2 provides additional detail on these reviews.

Our search for primary studies identified $\operatorname{six}^{13-18}$ that described components of the Patient Navigation Research Program (PNRP) sufficiently to address Question 1. We highlight PNRPrelated studies because the PNRP represents the single largest study of patient navigation to date: 10 different patient navigation programs across the country focused on breast, cervical, colorectal, and prostate cancers from 2005 to $2010 .^{19}$ Three of our identified studies ${ }^{13-15}$ focused on seven of the PNRP sites, two ${ }^{16,17}$ focused on a scaled-up county-wide adaptation of the 
PNRP, and one study ${ }^{18}$ examined navigators' work through field observations at nine PNRP sites. 
Table 2. Systematic reviews relevant to Question 1

\begin{tabular}{|c|c|c|c|c|c|}
\hline $\begin{array}{l}\text { Study Information } \\
\text { Author, Year } \\
\text { - \# Articles } \\
\text { - Navigation Focus } \\
\text { - Cancer Type } \\
\end{array}$ & $\begin{array}{c}\text { Navigator } \\
\text { Characteristics }\end{array}$ & $\begin{array}{c}\text { Team } \\
\text { Versus } \\
\text { Individual }\end{array}$ & $\begin{array}{c}\text { Setting } \\
\text { (Single SiteVversus } \\
\text { Health System) }\end{array}$ & Types of Services Delivered & $\begin{array}{l}\text { Patient Entry and } \\
\text { Exit Criteria }\end{array}$ \\
\hline $\begin{array}{l}\text { Bush } 2017^{11} \\
\text { - SR of } 16 \text { articles } \\
\text { - Diagnosis and } \\
\text { treatment } \\
\text { - Breast, cervical, } \\
\text { colorectal, or } \\
\text { prostate cancer }\end{array}$ & $\begin{array}{l}\text { Nine studies of lay } \\
\text { navigators, four } \\
\text { studies of nurses } \\
\text { with oncology } \\
\text { experience, seven } \\
\text { studies of a team } \\
\text { approach (lay } \\
\text { person and a nurse } \\
\text { or MSW). Some } \\
\text { studies had bilingual } \\
\text { navigators (English } \\
\text { \& Spanish). }\end{array}$ & $\begin{array}{l}\text { Both } \\
\text { individual } \\
\text { and team }\end{array}$ & NR & $\begin{array}{l}\text { Diagnostic studies: Structure of programs } \\
\text { varied across studies; some used } \\
\text { structured guide or assessment tools while } \\
\text { other used logging system to record } \\
\text { barriers or problems addressed during } \\
\text { patient encounters. Common barriers } \\
\text { included transportation, lack of insurance, } \\
\text { coordination of health care appointments, } \\
\text { language barriers, and general } \\
\text { misunderstanding of the follow-up process. } \\
\text { Treatment studies: NR }\end{array}$ & $\begin{array}{l}\text { Diagnostic studies } \\
\text { focused on medically } \\
\text { underserved patients } \\
\text { with abnormal cancer } \\
\text { screening. } \\
\text { Treatment studies } \\
\text { focused on medically } \\
\text { underserved patients } \\
\text { diagnosed with cancer. }\end{array}$ \\
\hline $\begin{array}{l}\text { Domingo } 2017^{6} \\
\text { - SR of eight } \\
\text { articles } \\
\text { - Screening } \\
\text { - Colorectal cancer }\end{array}$ & $\begin{array}{l}\text { Professional or } \\
\text { paraprofessional }\end{array}$ & NR & $\begin{array}{l}\text { Federally qualified } \\
\text { community health } \\
\text { centers (FQHC) }\end{array}$ & $\begin{array}{l}\text { Eight categories of navigation activities } \\
\text { provided in studies including: } \\
\text { - Screening education } \\
\text { - Client reminders } \\
\text { - Motivating/supporting patients } \\
\text { - Scheduling appts } \\
\text { - Translation assistance } \\
\text { - Arranging transport } \\
\text { - Ongoing barriers counseling } \\
\text { - Teaching test instructions }\end{array}$ & Minority FQHC clients \\
\hline
\end{tabular}




\begin{tabular}{|c|c|c|c|c|c|}
\hline $\begin{array}{l}\text { Study Information } \\
\text { Author, Year } \\
\text { - \# Articles } \\
\text { - Navigation Focus } \\
\text { - Cancer Type }\end{array}$ & $\begin{array}{c}\text { Navigator } \\
\text { Characteristics }\end{array}$ & $\begin{array}{c}\text { Team } \\
\text { Versus } \\
\text { Individual }\end{array}$ & $\begin{array}{c}\text { Setting } \\
\text { (Single SiteVversus } \\
\text { Health System) }\end{array}$ & Types of Services Delivered & $\begin{array}{l}\text { Patient Entry and } \\
\text { Exit Criteria }\end{array}$ \\
\hline $\begin{array}{l}\text { Hou } 2015^{7} \\
\text { - SR of } 27 \text { articles } \\
\text { - Screening } \\
\text { - Colorectal, } \\
\text { cervical, and } \\
\text { breast cancer }\end{array}$ & $\begin{array}{l}\text { Community-based } \\
\text { navigators were } \\
\text { recruited based on } \\
\text { bilingual skills and } \\
\text { length of residence } \\
\text { in target community. } \\
\text { Community and } \\
\text { clinic-based } \\
\text { navigators were } \\
\text { culture/language } \\
\text { concordant with } \\
\text { patients. Length and } \\
\text { intensity of navigator } \\
\text { training ranged from } \\
\text { 6-hour training to } \\
\text { several hundred } \\
\text { hours of programs. }\end{array}$ & NR & $\begin{array}{l}\text { Community-based (15 } \\
\text { studies in rural or } \\
\text { urban areas, } \\
\text { community-based } \\
\text { service programs, local } \\
\text { churches or academic } \\
\text { institutions working } \\
\text { with community } \\
\text { advisory boards) vs. } \\
\text { clinic/hospital-based } \\
\text { (12 studies in primary } \\
\text { care, hospitals, or } \\
\text { health care orgs). }\end{array}$ & $\begin{array}{l}\text { Roles and responsibilities: } \\
\text { - Reaching out to patients via mail, } \\
\text { phone, or face contacts } \\
\text { - Up to } 11 \text { attempts or } 2-3 \text { weeks of calls } \\
\text { were used in both settings. } \\
\text { - Provide educational information } \\
\text { - Host educational events } \\
\text { - Provide barrier counseling } \\
\text { - Share personal testimony } \\
\text { - Provide logistic support } \\
\text { - Serve as translator and advocate } \\
\text { - Gather information on access to } \\
\text { cancer care screenings } \\
\text { Community navigators more likely to do } \\
\text { face-to-face interactions, clinic-based } \\
\text { navigators more likely to send out } \\
\text { screening reminders or packages and } \\
\text { educational materials. }\end{array}$ & $\begin{array}{l}\text { Community-based } \\
\text { navigators often } \\
\text { identified racial/ethnic } \\
\text { minority patients } \\
\text { through community } \\
\text { networks or churches. } \\
\text { Clinic-based navigators } \\
\text { often identified low } \\
\text { income or mixed ethnic } \\
\text { group patients through } \\
\text { chart review, electronic } \\
\text { client database, or } \\
\text { referral by provider. }\end{array}$ \\
\hline
\end{tabular}




\begin{tabular}{|c|c|c|c|c|c|}
\hline $\begin{array}{l}\text { Study Information } \\
\text { Author, Year } \\
\text { - \# Articles } \\
\text { - Navigation Focus } \\
\text { - Cancer Type } \\
\end{array}$ & $\begin{array}{c}\text { Navigator } \\
\text { Characteristics }\end{array}$ & $\begin{array}{c}\text { Team } \\
\text { Versus } \\
\text { Individual }\end{array}$ & $\begin{array}{c}\text { Setting } \\
\text { (Single SiteVversus } \\
\text { Health System) }\end{array}$ & Types of Services Delivered & $\begin{array}{l}\text { Patient Entry and } \\
\text { Exit Criteria }\end{array}$ \\
\hline $\begin{array}{l}\text { Van Ee } 2016^{9} \\
\text { - SR of } 17 \text { articles } \\
\text { - Diagnosis and } \\
\text { treatment } \\
\text { - Breast, colorectal, } \\
\text { or ovarian cancer } \\
\text { or a range of } \\
\text { cancer types (with } \\
\text { lung as one type } \\
\text { included) }\end{array}$ & $\begin{array}{l}\text { Patient navigation } \\
\text { (PN) and patient } \\
\text { activation (PA) } \\
\text { primarily provided by } \\
\text { nurses }\end{array}$ & $\begin{array}{l}\text { Three PA } \\
\text { interventions } \\
\text { were } \\
\text { delivered by } \\
\text { an individual } \\
\text { nurse or } \\
\text { care } \\
\text { manager, } \\
\text { one PA } \\
\text { intervention } \\
\text { delivered by } \\
\text { nurses with } \\
\text { APNs } \\
\text { available } \\
24 / 7 \text {. }\end{array}$ & $\begin{array}{l}\text { Individual cancer } \\
\text { centers, VA medical } \\
\text { centers, and a mix of } \\
\text { community and public } \\
\text { hospitals }\end{array}$ & $\begin{array}{l}\text { Patient navigation models were not } \\
\text { described in detail. } \\
\text { Patient activation interventions focused on } \\
\text { older adults aimed to improve at least one } \\
\text { of the eight following care domains: } \\
\text { - Timeliness of care } \\
\text { - Health care utilization } \\
\text { - Quality of life } \\
\text { - Survival } \\
\text { - Symptom and activity levels } \\
\text { - Satisfaction with the intervention } \\
\text { - Information and support related } \\
\text { outcomes } \\
\text { - Perception of provider's role } \\
\text { Interventions ranged from transcription of } \\
\text { encounter to phone contacts to home visits } \\
\text { "Education, coordination, cognitive- } \\
\text { behavioural strategies, clinical assessment } \\
\text { and monitoring were among the strategies } \\
\text { used to increase the self-efficacy of } \\
\text { patients and the effectiveness of the care } \\
\text { they received." }\end{array}$ & $\begin{array}{l}\text { Older adults after the } \\
\text { detection of a screening } \\
\text { abnormality and before } \\
\text { entering the palliative } \\
\text { phase. }\end{array}$ \\
\hline
\end{tabular}

Abbreviations: APN=Advanced Practice Nurse; FQHC=Federally Qualified Health Center; MSW=Masters in Social Worker; NR=Not Reported; PA=Patient Activation;

$\mathrm{PN}=$ Patient Navigation; SR=Systematic Review; VA=Veterans Affairs 


\section{Navigator Characteristics}

\section{Systematic Reviews}

Patient navigation was delivered by both health care professionals ${ }^{9-12}$ (including nurses $^{10,11}$ and social workers ${ }^{11}$ ) and lay people. ${ }^{10,11}$ The training provided to navigators was highly variable, with one $\mathrm{SR}^{10}$ describing a range from a single six-hour training session to several hundred hours of programs. Navigators were paired to patients in terms of culture ${ }^{10}$ and language. ${ }^{10,11}$

\section{Primary Studies of the PNRP}

Navigators were required to have a high school diploma or General Education Diploma (GED) at minimum. ${ }^{19}$ Education of navigators ranged from high school diploma ${ }^{13,15}$ to masters level social ${ }^{15}$ work or public health. ${ }^{15,17}$ About two-thirds of navigators had a college or graduate degree. ${ }^{18}$ Both lay and health care professionals (e.g., social workers ${ }^{13,14}$ ) delivered patient navigation. About half of navigators had additional professional training (e.g., nurse, social worker, medical assistant, radiation technologist, medical translation). ${ }^{18}$

Navigators had a combination of local instruction and PNRP biannual trainings and webinars on the role of navigators, cancer research, screening, culture and diversity, and removal of barriers. ${ }^{13}$ At one site, PNRP training was supplemented by project leaders observing navigators weekly. ${ }^{13}$ At the county-wide adaptation of the PNRP, navigators received 80 hours of on-thejob training (e.g., local resources, administration, case manager shadowing at the local health department, community partner training) in addition to the national PNRP trainings. Similar to the programs in the SRs, navigators were paired with patients by culture and language. One of the PNRPs included promotoras (lay community health workers who are members of the Hispanic community). ${ }^{14}$ Of note, navigators often had experience with cancer, as 14 percent were cancer survivors and 45 percent reported cancer in their family. ${ }^{18}$

\section{Team Versus Individual}

\section{Systematic Reviews}

Both individual and team-based interventions were described in two SRs ${ }^{9,11}$ while the other two SRs ${ }^{6,7}$ did not report this characteristic of navigator programs. Team-based interventions included pairing a lay person with a health care professional (such as a nurse or social worker) or pairing a nurse with an advanced practice nurse available to patients $24 / 7 .^{9}$

\section{Primary Studies of the PNRP}

PNRP sites also described both individual and team-based navigator programs. The teambased interventions included pairing two lay people with two social workers. ${ }^{13}$ Another team approach paired a traditional navigator with a promotora (lay community health workers who are members of the Hispanic community) to specifically address cultural barriers of patients. ${ }^{14}$ 


\section{Setting}

\section{Systematic Reviews}

Navigation programs were delivered across diverse settings, including community (churches and community-based organizations), ${ }^{10}$ federally qualified health centers, ${ }^{9}$ individual cancer centers, ${ }^{12}$ primary care clinics, ${ }^{10}$ and large medical centers. ${ }^{10,12}$

\section{Primary Studies of the PNRP}

The PNRP also delivered navigation in diverse settings including federally qualified health centers, ${ }^{15}$ ambulatory care centers, ${ }^{15}$ academic health systems, ${ }^{14}$ and treatment units ${ }^{18}$ (e.g., chemotherapy infusion units). Within each PNRP site, most navigators worked across multiple health care locations (2 to 12$).{ }^{18}$

\section{Types of Services Provided}

\section{Systematic Reviews}

Navigators provided a range of services, including discussion and help overcoming barriers ${ }^{9-}$ ${ }^{11}$ (including transportation ${ }^{9,11}$ and translation ${ }^{9-11}$ ), scheduling and coordinating appointments, ${ }^{9,11}$ providing education and information on completing follow-up processes ${ }^{9-11}$ (such as how to complete an at-home fecal occult blood test), as well as patient activation strategies ${ }^{9,12}$ to promote patient engagement in care.

\section{Primary Studies of the PNRP}

While the PNRP had a common definition of patient navigation across sites, each site implemented navigation programs differently depending on their local staff and resources, and each site used a different study design. The PNRP defined patient navigation as support and guidance for vulnerable people with abnormal cancer screening or a cancer diagnosis, with the goal of overcoming barriers to timely, quality care in a culturally sensitive manner. ${ }^{19}$

The most comprehensive description of the myriad services delivered by patient navigators was found in a 2014 cluster analysis of field observations of 34 patient navigators at nine PNRP sites. ${ }^{18}$ Patient navigator tasks were divided into four main categories: navigating with individual patient by communication, supporting, instruction and coaching; facilitating care for patient via interaction with others; maintaining system of resources and relationships for patients; and information retrieval and medical record documentation. The analysis found six distinct patterns of work of patient navigators. Approximately 20 to 25 percent of navigators' total time was focused on one of three main work patterns: directly supporting patients through relatively long interactions (e.g., accompanying a patient to transfusion); interacting or coordinating with others for patients; or expediting care with patients, providers or clinical administrative staff. Interestingly, an additional one-quarter of their time was focused on tasks not interacting with patients: developing working relationships with community support agencies and medical record documentation. 


\section{Patient Entry and Exit Criteria}

\section{Systematic Reviews}

In the SRs, overall patient entry criteria were clearer than exit criteria. For screening, navigators identified patients through patient databases or chart reviews ${ }^{9,10}$ or community networks ${ }^{10}$ (such as churches). For diagnosis, navigation began after an abnormal screening test result. ${ }^{11,12}$ For treatment, navigation began after a definitive diagnosis. ${ }^{11,12}$ It was unclear when patients officially "exited" a navigation program, since most patients were only followed up to a given outcome (e.g., time to diagnostic resolution).

\section{Primary Studies of the PNRP}

Entry criteria were better described than exit criteria in the PNRP studies. For diagnosis, patients were referred to navigators after an abnormal screening test. ${ }^{14-16}$

Question 2. What is the effectiveness of patient navigation interventions for improving lung cancer outcomes across the spectrum of care?

\section{Systematic Reviews}

We did not identify any SRs examining the effectiveness of patient navigation interventions for improving lung cancer outcomes.

\section{Primary Studies}

We identified two completed studies (one randomized controlled trial [RCT $]^{20}$ and one mixed methods observational study ${ }^{21}$ ) and two ongoing studies ${ }^{22,23}$ evaluating the effectiveness of navigation services on lung cancer outcomes. See Table 3.

\section{Completed Studies}

A U.S.-based RCT $(n=1,200)^{20}$ examined the effects of a lay navigator program to increase lung cancer screening among current smokers. Four part-time lay navigators helped patients identify and overcome barriers to screening, empowered patients to discuss risks and benefits of screening with their primary care provider, provided brief smoking cessation counseling, and followed up with the appropriate provider after screening. The intervention group had higher rates of chest computed tomography (CTs) and lung cancer screening CTs. Patients were grouped by their Lung CT Screening Reporting and Data System (Lung-RADS) results, where Lung-RADS 1 or 2 findings did not require follow-up and Lung-RADS 3 or 4 required additional imaging and/or procedures. Both intervention and control groups had similar LungRADS findings, number of diagnoses, and time to follow-up care for Lung-RADS 4 patients.

A Canada-based mixed-methods observational study $(n=40)^{21}$ navigated patients with newly diagnosed lung cancer. Volunteer lay navigators contacted patients by phone, provided a tour of the cancer center, followed up with patients after the first visit with oncology, and provided an optional fourth contact if the patient's needs were not met. Patients reported being satisfied with the program. 
Table 3. Completed primary studies relevant to Question 2

\begin{tabular}{|c|c|c|c|c|}
\hline $\begin{array}{l}\text { Study Information } \\
\text { Author, year } \\
\text { - Study Type } \\
\text { - Navigation } \\
\text { Focus } \\
\text { - Country }\end{array}$ & Population & Intervention/Comparator & $\begin{array}{l}\text { Relevant } \\
\text { Outcomes }\end{array}$ & Results \\
\hline $\begin{array}{l}\text { Percac-Lima } 2018^{20} \\
\text { - RCT } \\
\text { - Screening } \\
\text { - United States }\end{array}$ & $\begin{array}{l}\mathrm{n}=1,200 \\
\text { patients at } \\
\text { five } \\
\text { community } \\
\text { health centers } \\
\text { Eligibility } \\
\text { criteria } \\
\text { included } \\
\text { current } \\
\text { smokers aged } \\
55-77 \text { years } \\
\text { old }\end{array}$ & $\begin{array}{l}\text { Intervention (n=400): Lay } \\
\text { navigators did the } \\
\text { following: } \\
\text { 1. Initial interview to } \\
\text { determine smoking } \\
\text { history/eligibility } \\
\text { 2. Identify and help } \\
\text { patients overcome } \\
\text { barriers } \\
\text { 3. Introduce shared } \\
\text { decision-making } \\
\text { 4. Empower patients to } \\
\text { discuss risks and } \\
\text { benefits of screening } \\
\text { with PCP } \\
\text { 5. Review CT lung } \\
\text { cancer screening } \\
\text { reports and contact } \\
\text { provider about follow- } \\
\text { up care } \\
\text { 6. Provide brief smoking } \\
\text { cessation counseling }\end{array}$ & $\begin{array}{l}\text { - Proportion of } \\
\text { patients } \\
\text { receiving chest } \\
\text { CT scan for } \\
\text { screening or } \\
\text { diagnosis } \\
\text { - Proportion of } \\
\text { patients } \\
\text { receiving lung } \\
\text { cancer } \\
\text { screening CTs } \\
\text { - Results of } \\
\text { screening CTs } \\
\text { (Lung-RADS } \\
\text { scale) } \\
\text { - Lung cancer } \\
\text { diagnoses } \\
\text { - Time to follow- } \\
\text { up of patients } \\
\text { with Lung- } \\
\text { RADS } 4\end{array}$ & $\begin{array}{l}\text { - A greater proportion of } \\
\text { intervention patients } \\
\text { had chest CTs } \\
\text { compared with patients } \\
\text { in control group (31\% } \\
\text { vs. } 17 \%, p<0.001 \text { ). } \\
\text { - Lung cancer screening } \\
\text { CTs performed more } \\
\text { often in intervention } \\
\text { than control group } \\
\text { (23.5\% vs. 8.6\%, p< } \\
\text { 0.001). } \\
\text { - Similar rates of Lung- } \\
\text { RADS findings } \\
\text { between intervention } \\
\text { and control groups } \\
\text { (p=0.72). Most had } \\
\text { Lung-RADS } 1 \text { or } 2 \text { (no } \\
\text { follow-up needed). } \\
\text { - Intervention group had } \\
\text { eight diagnoses of lung } \\
\text { cancer vs. four in } \\
\text { control ( } p \text {-value NR). } \\
\text { - Intervention group } \\
\text { patients with Lung- } \\
\text { RADS } 4 \text { findings had } \\
20.1 \text { days to follow up } \\
\text { vs. } 22 \text { days in control } \\
\text { (p-value NR). }\end{array}$ \\
\hline $\begin{array}{l}\text { Lorhan } 2014^{21} \\
\text { - Mixed-methods } \\
\text { observational } \\
\text { (quantitative } \\
\text { data from post- } \\
\text { intervention } \\
\text { survey) } \\
\text { - Treatment } \\
\text { - Canada }\end{array}$ & $\begin{array}{l}\mathrm{n}=40 \text { patients } \\
\text { with newly } \\
\text { diagnosed } \\
\text { lung cancer }\end{array}$ & $\begin{array}{l}\text { Intervention: } \\
\text { Volunteer lay navigators } \\
\text { provided three steps with } \\
\text { an optional fourth step: } \\
\text { 1. Introduction phone } \\
\text { call } \\
\text { 2. Meet patient for tour } \\
\text { of cancer center and } \\
\text { discussion } \\
\text { 3. Closure phone call } \\
\text { after visit with } \\
\text { oncologist } \\
\text { 4. Additional support as } \\
\text { requested by } \\
\text { participants whose } \\
\text { needs were not fully } \\
\text { addressed } \\
\text { Comparator: None }\end{array}$ & $\begin{array}{l}\text { Satisfaction with } \\
\text { program }\end{array}$ & $\begin{array}{l}\text { Participants scored their } \\
\text { satisfaction as } 4.3 \text { on a } \\
\text { scale from one (not } \\
\text { satisfied) to five (very } \\
\text { satisfied). }\end{array}$ \\
\hline
\end{tabular}

Abbreviations: CT=Computed Tomography; Lung-RADS=Lung imaging reporting and data system; NR=Not Reported; PCP=Primary Care Physician; RCT=Randomized Controlled Trial 


\section{Protocols and Clinical Trials}

Our search identified two ongoing studies. ${ }^{22,23}$ One U.S.-based RCT ${ }^{23}$ will examine the effectiveness of patient navigation for increasing lung cancer screening among a racially diverse, medically underserved population served by a safety-net health system. Patients $(n=170)$ who are at high risk of cancer will be randomized to usual care or usual care plus navigation. Navigators will educate, motivate, and empower patients to schedule appointments for CT scans, inquire about interest in smoking cessation, remind patients about upcoming appointments, and follow up after the scan to refer patients to appropriate care. The RCT will measure adherence to cancer screenings, as well as patient attitudes and beliefs (including cancer worry, psychosocial distress, and patient satisfaction).

One U.S.-based randomized, open-label study ${ }^{22}(n \approx 200)$ will examine the effectiveness of nurse-led patient navigation in early stage non-small cell lung cancer (NSCLC) treatment in African Americans ages 21 and older. The primary outcome of interest is the receipt of lungdirected therapy with curative intent and, secondarily, time to therapy. Other secondary outcomes of interest include receipt of surgical/radiation oncology consultation, satisfaction with care, and time to death. The role of the nurse-led patient navigation is not well-defined in this study, but is generally to provide solutions of potential barriers to treatment and to engage in direct communication with patients at least once a week. See Table 4.

Table 4. Protocols and clinical trials relevant to Questions 2 and 3

\begin{tabular}{|c|c|c|c|c|}
\hline $\begin{array}{l}\text { Study Information } \\
\text { Author, Year } \\
\text { - Study Type } \\
\text { - Navigation } \\
\text { Focus } \\
\text { - Country }\end{array}$ & Population & Intervention/Comparator & $\begin{array}{l}\text { Relevant } \\
\text { Outcomes }\end{array}$ & $\begin{array}{l}\text { Results (if } \\
\text { Available) }\end{array}$ \\
\hline $\begin{array}{l}\text { Gerber } 2017^{23} \\
\text { - RCT protocol } \\
\text { - Screening } \\
\text { - United States }\end{array}$ & $\begin{array}{l}\mathrm{n}=340 \text { medically } \\
\text { underserved and } \\
\text { racially diverse } \\
\text { patients at high } \\
\text { risk of lung cancer } \\
\text { Eligibility criteria } \\
\text { included age 55- } \\
77 \text { years, smoking } \\
\text { history } \geq 30 \text { pack- } \\
\text { years, quit within } \\
15 \text { years if former } \\
\text { smoker }\end{array}$ & $\begin{array}{l}\text { Intervention: Usual care plus } \\
\text { navigation (navigators will } \\
\text { educate, motivate, and } \\
\text { empower patients to schedule } \\
\text { appointments for CT scans, } \\
\text { inquire about interest in } \\
\text { smoking cessation, remind } \\
\text { patients about upcoming } \\
\text { appointments, and follow up } \\
\text { after the scan to refer patients } \\
\text { to appropriate care). } \\
\text { Comparator: Usual care }\end{array}$ & $\begin{array}{l}\text { Adherence to } \\
\text { cancer screening } \\
\text { Cancer worry } \\
\text { Psychosocial } \\
\text { distress } \\
\text { Satisfaction with } \\
\text { care }\end{array}$ & In process \\
\hline
\end{tabular}




\begin{tabular}{|c|c|c|c|c|}
\hline $\begin{array}{l}\text { Study Information } \\
\text { Author, Year } \\
\text { - Study Type } \\
\text { - Navigation } \\
\text { Focus } \\
\text { - Country }\end{array}$ & Population & Intervention/Comparator & $\begin{array}{l}\text { Relevant } \\
\text { Outcomes }\end{array}$ & $\begin{array}{l}\text { Results (if } \\
\text { Available) }\end{array}$ \\
\hline $\begin{array}{l}\text { Wake Forest } \\
\text { University Health } \\
\text { Services } 2018^{22} \\
\text { - Randomized, } \\
\text { Open-Label. } \\
\text { ClinicalTrials.gov } \\
\text { NCT01885455 } \\
\text { - Treatment } \\
\text { - United States }\end{array}$ & $\begin{array}{l}\mathrm{n} \approx 200 \text { African } \\
\text { Americans ( } 21 \\
\text { years or older) } \\
\text { with clinically } \\
\text { suspicious or } \\
\text { biopsy-proven, } \\
\text { early stage non- } \\
\text { small-cell lung } \\
\text { cancer }\end{array}$ & $\begin{array}{l}\text { Intervention: Nurse-led PN + } \\
\text { standard therapy/usual care. } \\
\text { PN will provide an NCl lung } \\
\text { cancer booklet and } \\
\text { encourage engagement with } \\
\text { diagnosing physician. PN will } \\
\text { contact each participant by } \\
\text { telephone or in-person at } \\
\text { least once per week. PNs } \\
\text { identify and work to reduce } \\
\text { barriers to treatment. } \\
\text { Comparator: Usual care, } \\
\text { including complete staging } \\
\text { work-up, surgical } \\
\text { consultation, cardiac/ } \\
\text { pulmonary function testing, } \\
\text { surgical resection, adjuvant } \\
\text { therapy }\end{array}$ & $\begin{array}{l}\text { Receipt of lung- } \\
\text { directed therapy } \\
\text { with curative intent } \\
\text { (LDTCI) } \\
\text { Receipt of surgical } \\
\text { and/or radiation } \\
\text { oncology } \\
\text { consultation } \\
\text { Time to LDTCl } \\
\text { Satisfaction with } \\
\text { care received } \\
\text { Time to death }\end{array}$ & $\begin{array}{l}\text { Study is still } \\
\text { recruiting. No } \\
\text { results }\end{array}$ \\
\hline
\end{tabular}

Abbreviations: CT=Computed Tomography; LDCTI=Lung-Directed Therapy with Curative Intent; NCI=National Cancer Institute; PN=Patient Navigation; RCT=Randomized Controlled Trial

Question 3. Does the effectiveness of patient navigation interventions for improving lung cancer outcomes vary by geographic location (rural, suburban, urban), socioeconomic status, literacy, or race/ethnicity?

\section{Systematic Reviews}

We did not identify any SRs examining the effectiveness of patient navigation interventions for improving lung cancer outcomes for specific patient subgroups of geographic location, socioeconomic status, literacy, or race/ethnicity.

\section{Primary Studies}

\section{Completed Studies}

We did not find any completed studies which addressed lung cancer outcomes by patient subgroups of geographic location, socioeconomic status, literacy, or race/ethnicity.

\section{Ongoing Studies}

One U.S.-based randomized, open-label $\operatorname{study}^{22}(n \approx 200)$ will examine the effectiveness of nurse-led patient navigation in early stage NSCLC treatment in African Americans ages 21 and older. See Table 4 for additional information.

\section{Ongoing Efforts}

There are several ongoing efforts in the development and improvement of patient navigation programs. These efforts include guidelines, national standards used by health care systems and 
government agencies, and volunteer-based grassroots efforts. The following is not a comprehensive list, rather examples found during this workup and identified during conversation with a patient navigation expert.

\section{Guidelines}

A 2012 United Kingdom National Institute for Health and Clinical Excellence (NICE) guideline on lung cancer requires that all people with known or suspected lung cancer have access to a clinical nurse specialist (the UK term for nurse navigator) who they can contact between visits. Furthermore the guideline requires that health systems track three quality metrics: the proportion of patients with known or suspected lung cancer who receive the name and contact number of a lung cancer clinical nurse specialist, the proportion of patients with lung cancer who had a lung cancer clinical nurse specialist at diagnosis, and the proportion of patient with lung cancer who were assessed by a lung cancer clinical nurse specialist. ${ }^{24}$

\section{Standards}

The U.S.-based Commission on Cancer (CoC) updated their cancer care standards for hospitals and cancer centers in 2016. This commission, a program of the American College of Surgeons, “...recognizes cancer care programs for their commitment to providing comprehensive, high-quality, and multidisciplinary patient centered care.”25 Many government agencies (e.g., Centers for Medicare \& Medicaid Services) and health care systems look to these standards to assist with quality reporting. Accreditation by the $\mathrm{CoC}$ does not require the hiring of a patient navigator, but rather provides a framework for reducing disparities and barriers to care. While comprehensive and multifaceted, the standards highlight the importance of a multidisciplinary team approach to cancer care, the use of a designated oncology nurse manager, community outreach for prevention and screening with follow-up, and the use of a community needs assessment to better target potential barriers of care in the community.

\section{Toolkits}

The Boston Medical Center (BMC), in a partnership with the Avon Foundation for Women, developed a patient navigation toolkit. ${ }^{26}$ This navigation model was designed and studied ${ }^{27,}{ }^{28}$ for breast cancer services but has been adopted to other oncological and chronic disease services in the BMC. The patients in the patient navigation group demonstrated higher mammogram adherence than in the control group $(\mathrm{p}<0.001),{ }^{28}$ and were more likely to follow-up within 120 days of the initial appointment (39\% greater odds, 95\% confidence interval, 1.01-1.9). ${ }^{27}$ This toolkit, using evidence- and experience-based examples, aims to help other health care systems develop patient navigation programs to reduce health disparities and improve health outcomes. This toolkit focuses on the logistics of launching a patient navigation program, and is therefore geared toward program and project managers, but provides valuable resources for conducting needs assessments and examples of patient navigator qualifications and job descriptions.

A Patient Navigation Manual for Latino Audiences: The Redes En Acción Experience ${ }^{29}$ is a toolkit developed by a team of researchers, and studied in a network of six hospitals ${ }^{30}$ (Redes En Acción: The National Latino Cancer Research Network, in San Francisco, San Diego, New York, Miami, Houston, and San Antonio [primary study site in San Antonio]). This patient navigation program demonstrated an increase in the percentage of Latinas initiating breast cancer treatment within 30 and 60 days of diagnosis compared to controls $(p=0.045$ and $p=0.021$, 
respectively). ${ }^{30}$ Like the BMC toolkit, this patient navigator manual was initially studied in breast cancer patients, and has since been adopted to other oncologic specialties. This toolkit has a primary emphasis on Latino populations, and related factors such as cultural competency and overcoming barriers to care.

\section{Other Programs and Resources}

The University of California (UC) system has a number of patient navigation programs, specific to individual university hospitals. UC San Francisco hosts a program called the Patient Support Corps, which relies on volunteer efforts from undergraduates (from UC Berkeley) and pre-medical interns (college graduates). ${ }^{31}$ These volunteers provide materials, services, and referrals to help those with cancer diagnoses review information, list questions they have about their diagnosis, and take notes and recordings of medical appointments. The UCLA Health Care Extender Program is also a volunteer program, wherein extenders are trained and then gain hands-on experience in the medical field, interact with patients and family, learn strategies to overcome barriers to care and difficult medical situations, and assist staff with their duties in the unit. $^{32}$

Most patient navigation programs require training for navigators. One of the most common training programs is provided by The Harold Freeman Institute. ${ }^{33}$ The institute provides two-day training programs for patient navigators. This program emphasizes the elimination of barriers to timely care. The Harold Freeman Institute trains navigators to facilitate “...movement of an individual across the entire health care continuum from prevention, detection, diagnosis, treatment, and supportive, to end-of-life care."33

\section{Discussion}

We found only two completed studies on patient navigation programs from the past 5 yearsaddressing lung cancer at any point in the cancer continuum, one on lung cancer screening using paid lay navigators and one on newly diagnosed lung cancer patients using volunteer lay navigators. This limited evidence shows that patient navigation may improve rates of screening or diagnostic CTs, and that patients with newly diagnosed lung cancer may be satisfied with a volunteer patient navigation program. It will be important for future studies to address other important considerations, including if patients' screening decisions are aligned with their goals and preferences and comparing the effectiveness of volunteer lay navigators with paid lay navigators on the effectiveness of cancer outcomes as well as patient satisfaction.

Regarding all types of cancer, our findings from both SRs and PNRP-related studies confirms the wide variation among programs with respect to navigator characteristics (education, training, and cultural background), type of program (team versus individual), health care setting, and types of services provided. Entry criteria were often similar among programs (e.g., an abnormal screening test), but exit criteria were usually not defined. Most of the evidence we identified focused on breast, cervical, colorectal and prostate cancer.

This report found that navigators primarily deliver two types of services. ${ }^{18}$ First they work with patients, providers, staff and families to resolve problems and barriers to care. Second, they work to provide fixes to a broken health care system by facilitating communication and coordination between staff and systems to prevent lapses in care (e.g., transcribing medical records between medical systems). 
Overall there is broad consensus on the general definition of patient navigation for cancer, mostly focusing on Harold Freeman's original vision of models to address barriers to care in a culturally sensitive manner for the most vulnerable patients as determined by race, language, income, or rural location. ${ }^{5}$ However, the specific details of how to implement a program are not agreed upon or prescribed by any guideline organizations at this time. Although it has been 28 years since Freeman's original conception, patient navigation programs have proliferated but there is no consensus on the ideal components.

\section{Limitations of Review Methodology}

This rapid evidence product used accelerated methods in order to complete the work on a rapid timeline for our nominator. Because our nominator was interested broadly in the components of navigation program and how to implement them, we determined that an evidence product with less scientific rigor was appropriate. We did not complete many steps of a traditional SR, including risk of bias evaluation. Therefore, these findings may have less certainty compared to those of an SR. We also may have missed studies since we narrowed the SR search to the past three years and the primary study search to the past five years. In addition, due to time constraints, we excluded qualitative studies, which limits our ability to explain why certain components of navigation programs work and the mechanism by which they improve patient's cancer care.

\section{Implications for Future Research}

While patient navigation interventions are a desired element of the continuum of all types of cancer care, it is important to highlight that there is no need to reinvent the wheel. Even though the evidence showing efficacy of these models and their application specifically to lung cancer is sparse, there is substantial evidence for effectiveness of patient navigation in other types of cancer. We previously mentioned interventions and toolkits that were initially designed for breast cancer care, but were later adapted for use in other cancer types. These evidence-based toolkits describe how to develop patient navigation models, which are intended to be frameworks on which tailored programs can be built. We recommend researchers conduct implementation studies to determine which model is the most effective for which cancer type in which health system.

We also recommend researchers describe patient navigation interventions in as much detail as possible, including navigators' duties, training, and characteristics. Despite a national research collaborative dedicated to patient navigation (e.g., the PNRP), studies were notable for their considerable lack of detailed descriptions on individual patient navigation programs. It was often difficult to determine what patient navigators actually did, beyond the general definition set forth by the PNRP program. ${ }^{19}$ The SRs on patient navigation programs for all cancers also did not provide granular descriptions. This lack of clarity makes it difficult to interpret the effectiveness results of the studies and difficult for others to replicate the navigator interventions.

Lung cancer presents certain challenges which may not be relevant for patients with other cancers, including that lung cancer often presents at an advanced stage with a more rapid and fatal course. In addition, lung cancer patients often have more physical and psychological needs and a significant portion of lung cancer patients may benefit from behavioral counseling (e.g., 
smoking cessation). ${ }^{34}$ Therefore additional studies on lung cancer patient navigation may be warranted to determine the ideal adaptations of navigation programs for these patients.

Finally, we recommend recruiting diverse populations; including race, ethnicity, socioeconomic status, and geographic location; and analyzing results by subgroups. Of the limited evidence on lung cancer, only one ongoing RCT examined effectiveness in African Americans, and does not compare across subgroups of other races or ethnicities. ${ }^{22}$ 


\section{References}

1. Hartling L, Guise J-M, Hempel S, et al. EPC methods: AHRQ End-user perspectives of rapid reviews. Rockville (MD): 2016. https://www.ncbi.nlm.nih.gov/pubmed/2719 $\underline{5347}$

2. Hartling L, Guise JM, Kato E, et al. EPC Methods: An Exploration of Methods and Context for the Production of Rapid Reviews. Rockville (MD): 2015. https://www.ncbi.nlm.nih.gov/pubmed/2565 $\underline{4160}$

3. Hartling L, Guise J-M, Hempel S, et al. Fit for purpose: perspectives on rapid reviews from end-user interviews. Systematic Reviews. 2017;6:32. doi: 10.1186/s13643017-0425-7. PMID: PMC5316162.

4. American Cancer Society. Cancer facts and Figures. Available from: https://www.cancer.org/content/dam/cancerorg/research/cancer-facts-andstatistics/annual-cancer-facts-andfigures/2018/cancer-facts-and-figures2018.pdf. 2018.

https://www.cancer.org/content/dam/cancerorg/research/cancer-facts-andstatistics/annual-cancer-facts-andfigures/2018/cancer-facts-and-figures2018.pdf. Accessed on August 12018.

5. Freeman HP, Rodriguez RL. History and principles of patient navigation. Cancer. 2011 Aug;117(15 Suppl):3539-42. Available from:

https://www.ncbi.nlm.nih.gov/pubmed/2178 0088. doi: 10.1002/cncr.26262. PMID: 21780088.

6. Role of the Oncology Nurse Navigator Throughout the Cancer Trajectory. Oncol Nurs Forum. 2018 May 1;45(3):283. Available from: https://www.ncbi.nlm.nih.gov/pubmed/2968 3124. doi: 10.1188/18.onf.283. PMID: 29683124.

7. H.R. 1812 (109th): Patient Navigator Outreach and Chronic Disease Prevention Act of 2005. 2005. https://www.govtrack.us/congress/bills/109/ hr1812.
8.

Wells KJ, Nuhaily S. Models of patient navigation. Patient Navigation. Springer; 2018:27-40. Available from:

https://www.springer.com/cda/content/docu ment/cda_downloaddocument/97814939697 77-c2.pdf?SGWID=0-0-45-1607900p180676933.

9. Domingo J-LB, Braun KL. Characteristics of Effective Colorectal Cancer Screening Navigation Programs in Federally Qualified Health Centers: A Systematic Review. J Health Care Poor Underserved. 2017;28(1):108-26. Available from: https://www.ncbi.nlm.nih.gov/pubmed/?ter $\mathrm{m}=28238992$. doi: https://dx.doi.org/10.1353/hpu.2017.0013.

10. Hou S-I, Roberson K. A systematic review on US-based community health navigator (CHN) interventions for cancer screening promotion--comparing community- versus clinic-based navigator models. J Cancer Educ. 2015;30(1):173-86. Available from: https://www.ncbi.nlm.nih.gov/pubmed/?ter $\underline{m}=25219543$. doi:

https://dx.doi.org/10.1007/s13187-0140723-X.

11. Bush ML, Kaufman MR, Shackleford T. Adherence in the Cancer Care Setting: a Systematic Review of Patient Navigation to Traverse Barriers. J Cancer Educ. 2017:Available from: https://www.ncbi.nlm.nih.gov/pubmed/?ter $\underline{m}=28567667$. doi:

https://dx.doi.org/10.1007/s13187-017$\underline{1235-2}$.

12. van Ee IB, Hagedoorn M, Slaets JPJ, et al. Patient navigation and activation interventions for elderly patients with cancer: A systematic review. Eur J Cancer Care. 2017;26(2):Available from: https://www.ncbi.nlm.nih.gov/pubmed/?ter $\underline{m=27991704}$. doi:

https://dx.doi.org/10.1111/ecc.12621.

13. Tejeda S, Darnell JS, Cho YI, et al. Patient barriers to follow-up care for breast and cervical cancer abnormalities. J Womens Health (Larchmt). 2013 Jun;22(6):507-17. Available from: https://www.ncbi.nlm.nih.gov/pubmed/2367 2296. doi: 10.1089/jwh.2012.3590. PMID: 23672296. 
14. Paskett ED, Dudley D, Young GS, et al. Impact of Patient Navigation Interventions on Timely Diagnostic Follow Up for Abnormal Cervical Screening. J Womens Health (Larchmt). 2016 Jan;25(1):15-21. Available from: https://www.ncbi.nlm.nih.gov/pubmed/?ter $\underline{m=26625131}$. doi: 10.1089/jwh.2014.5094. PMID: 26625131.

15. Katz ML, Young GS, Reiter PL, et al. Barriers reported among patients with breast and cervical abnormalities in the patient navigation research program: impact on timely care. Womens Health Issues. 2014 Jan-Feb;24(1):e155-62. Available from: https://www.ncbi.nlm.nih.gov/pubmed/?ter $\mathrm{m}=24439942$. doi:

10.1016/j.whi.2013.10.010. PMID: 24439942.

16. Simon MA, Tom LS, Nonzee NJ, et al. Evaluating a bilingual patient navigation program for uninsured women with abnormal screening tests for breast and cervical cancer: implications for future navigator research. Am J Public Health. 2015 May;105(5):e87-94. Available from: https://www.ncbi.nlm.nih.gov/pubmed/?ter $\mathrm{m}=25713942$. doi:

10.2105/ajph.2014.302341. PMID: 25713942.

17. de la Riva EE, Hajjar N, Tom LS, et al. Providers' Views on a Community-Wide Patient Navigation Program: Implications for Dissemination and Future Implementation. Health Promot Pract. 2016 May;17(3):382-90. Available from: https://www.ncbi.nlm.nih.gov/pubmed/?ter $\underline{m=27009130}$. doi:

10.1177/1524839916628865. PMID: 27009130.

18. Clark JA, Parker VA, Battaglia TA, et al. Patterns of task and network actions performed by navigators to facilitate cancer care. Health Care Manage Rev. 2014 AprJun;39(2):90-101. Available from: https://www.ncbi.nlm.nih.gov/pubmed/?ter $\underline{\mathrm{m}=23478753}$. doi:

10.1097/HMR.0b013e31828da41e. PMID: 23478753.
19. Freund KM, Battaglia TA, Calhoun E, et al. National Cancer Institute Patient Navigation Research Program: methods, protocol, and measures. Cancer. 2008 Dec 15;113(12):3391-9. Available from: https://www.ncbi.nlm.nih.gov/pubmed/?ter $\underline{m=18951521}$. doi: 10.1002/cncr.23960. PMID: 18951521.

20. Percac-Lima S, Ashburner JM, Rigotti NA, et al. Patient navigation for lung cancer screening among current smokers in community health centers a randomized controlled trial. Cancer Med. 2018 Mar;7(3):894-902. Available from: https://www.ncbi.nlm.nih.gov/pubmed/?ter $\underline{\mathrm{m}=29464877}$. doi: 10.1002/cam4.1297. PMID: 29464877.

21. Lorhan S, Dennis D, van der Westhuizen M, et al. The experience of people with lung cancer with a volunteer-based lay navigation intervention at an outpatient cancer center. Patient Educ Couns. 2014 Aug;96(2):23748. Available from: https://www.ncbi.nlm.nih.gov/pubmed/?ter $\underline{m=24862912}$. doi:

10.1016/j.pec.2014.05.002. PMID: 24862912.

22. Wake Forest University Health Services. Improving Resection Rates Among Africal Americans with NSCLC. ClinicalTrials.gov. 2018; NCT001885455. Available from: https://clinicaltrials.gov/ct2/show/NCT0188 $\underline{5455}$.

23. Gerber DE, Hamann HA, Santini NO, et al. Patient navigation for lung cancer screening in an urban safety-net system: Protocol for a pragmatic randomized clinical trial. Contemp Clin Trials. 2017 Sep;60:78-85. Available from: https://www.ncbi.nlm.nih.gov/pubmed/?ter $\underline{\mathrm{m}=28689056}$. doi: 10.1016/j.cct.2017.07.003. PMID: 28689056.

24. National Institute for Health and Care Excellence. Next Quality statement 4: Lung cancer clinical nurse specialist.

https://www.nice.org.uk/guidance/qs17/chap ter/quality-statement-4-lung-cancer-clinicalnurse-specialist. 2012.

https://www.nice.org.uk/guidance/qs17/chap ter/quality-statement-4-lung-cancer-clinicalnurse-specialist. Accessed on Aug 12018. 
25. Cancer ACoSCo. American College of Surgeons Commission on Cancer. Cancer Program Standards: Ensuring PatientCentered Care, 2016 ed. Available from: https://www.facs.org/qualityprograms/cancer/coc/standards.

26. Boston Medical Center. The Boston Medical Center Patient Navigation Toolkit. Available from:

https://nciphub.org/resources/1600/downloa d/BMC_Patient_Navigation_Toolkit_-

Vol_1.pdf. 2012.

https://nciphub.org/resources/1600/downloa d/BMC_Patient_Navigation_Toolkit_-

_Vol_1.pdf. Accessed on July 302018.

27. Battaglia TA, Roloff K, Posner MA, et al. Improving follow-up to abnormal breast cancer screening in an urban population. A patient navigation intervention. Cancer. 2007 Jan 15;109(2 Suppl):359-67. Available from:

https://www.ncbi.nlm.nih.gov/pubmed/?ter $\mathrm{m}=17123275$. doi: 10.1002/cncr.22354.

PMID: 17123275.

28. Phillips CE, Rothstein JD, Beaver K, et al. Patient navigation to increase mammography screening among inner city women. J Gen Intern Med. 2011 Feb;26(2):123-9. Available from: https://www.ncbi.nlm.nih.gov/pubmed/?ter $\underline{m=20931294}$. doi: $10.1007 / s 11606-010$ 1527-2. PMID: 20931294.

29. Acción RE. The National Latino Cancer Research Network. A Patient Navigation Manual for Latino Audiences: The Redes En Acción Experience. Available from: http://www.chcact.org/resourcefiles/PNmanualfinal.pdf. 2012.

30. Ramirez A, Perez-Stable E, Penedo F, et al. Reducing time-to-treatment in underserved Latinas with breast cancer: the Six Cities Study. Cancer. 2014 11/12;120(5):752-60. Available from: https://www.ncbi.nlm.nih.gov/pubmed/?ter m=24222098. doi: 10.1002/cncr.28450. PMID: PMC3949173.

31. UCSF Patient Support Corps. Available from: https://pst.ucsf.edu/. 2018. https://pst.ucsf.edu/. Accessed on August 1 2018.
32. UCLA Care Extender Program. Available from:

https://www.uclahealth.org/careextender/car e-extender-program. 2018.

https://www.uclahealth.org/careextender/car e-extender-program. Accessed on August 1 2018.

33. Harold P. Freeman Patient Navigation Institute. Available from: http://www.hpfreemanpni.org/. 2018. http://www.hpfreemanpni.org/. Accessed on August 12018.

34. Husain A, Barbera L, Howell D, et al. Advanced lung cancer patients' experience with continuity of care and supportive care needs. Support Care Cancer. 2013 May;21(5):1351-8. Available from: https://www.ncbi.nlm.nih.gov/pubmed/2327 4923. doi: 10.1007/s00520-012-1673-7.

PMID: 23274923. 


\section{Appendix A. Search Strategies}

\section{Ovid MEDLINE(R) and Epub Ahead of Print, In-Process \& Other Non-Indexed Citations, and Daily 1946 to July 18, 2018}

Date Searched: July 19, 2018

Searched by: Information Specialist

\begin{tabular}{|c|c|}
\hline \# & Searches \\
\hline 1 & Patient Navigation/ \\
\hline 2 & ((lay or layperson or nurse ${ }^{*}$ or patient* or peer* $^{*}$ or "social work*" or volunteer*) adj3 navigat").tw,kf. \\
\hline 3 & or/1-2 \\
\hline 4 & $\begin{array}{l}\text { exp neoplasms/ or exp cysts/ or exp hamartoma/ or exp neoplasms by histologic type/ or exp neoplasms by site/ } \\
\text { or exp neoplasms, experimental/ or exp neoplasms, hormone-dependent/ or exp neoplasms, multiple primary/ or } \\
\text { exp neoplasms, post-traumatic/ or exp neoplasms, radiation-induced/ or exp neoplasms, second primary/ or exp } \\
\text { neoplastic processes/ or exp neoplastic syndromes, hereditary/ or exp paraneoplastic syndromes/ or exp } \\
\text { precancerous conditions/ or exp pregnancy complications, neoplastic/ }\end{array}$ \\
\hline 5 & (cancer ${ }^{\star}$ or neoplasm ${ }^{\star}$ or blastoma ${ }^{\star}$ or carcinoma* or metastat $\left.{ }^{\star}\right) . \mathrm{tw}, \mathrm{kf}$. \\
\hline 6 & or/4-5 \\
\hline 7 & $\begin{array}{l}\text { exp Lung Neoplasms/ or Bronchial Neoplasms/ or Carcinoma, Bronchogenic/ or Multiple Pulmonary Nodules/ or } \\
\text { Pancoast Syndrome/ or Pulmonary Blastoma/ or Pulmonary Sclerosing Hemangioma/ or Adenocarcinoma in Situ/ } \\
\text { or Adenocarcinoma, Bronchiolo-Alveolar/ or Carcinoma, Non-Small-Cell Lung/ or Small Cell Lung Carcinoma/ }\end{array}$ \\
\hline 8 & (adenocarcinoma or ((lung* or pulmonary or bronch*) adj3 (cancer* or neoplasm or carcinoma*))).ti,kf. \\
\hline 9 & or/7-8 \\
\hline 10 & and $/ 3,6$ \\
\hline 11 & and $/ 3,9$ \\
\hline 12 & 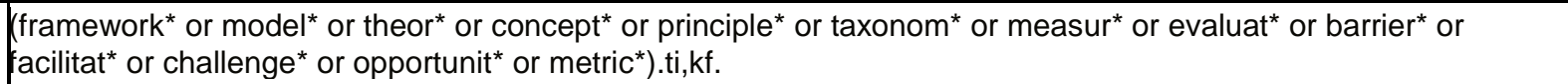 \\
\hline 13 & This row general cancer models \\
\hline 14 & This row lung cancer models \\
\hline 15 & randomized controlled trial.pt. \\
\hline 16 & controlled clinical trial.pt. \\
\hline 17 & randomized controlled trials as topic/ \\
\hline 18 & random allocation/ \\
\hline 19 & double-blind method/ \\
\hline 20 & single-blind method/ \\
\hline 21 & clinical trial.pt. \\
\hline 22 & exp clinical trial as topic/ \\
\hline 23 & $\left(\right.$ clin* adj25 trial*).ti,ab. $^{\circ}$ \\
\hline 24 & $\left(\left(\right.\right.$ single ${ }^{\star}$ or doubl ${ }^{\star}$ or trebl* or tripl*) adj25 (blind* or mask* $\left.\left.{ }^{\star}\right)\right) . t i, a b$. \\
\hline 25 & placebos/ \\
\hline 26 & placebo*.ti,ab. \\
\hline 27 & random*.ti,ab. \\
\hline 28 & research design/ \\
\hline 29 & comparative studyl \\
\hline 30 & exp evaluation studies/ \\
\hline
\end{tabular}




\begin{tabular}{|c|c|}
\hline \# & Searches \\
\hline 31 & follow up studies/ \\
\hline 32 & prospective studies/ \\
\hline 33 & (control* or prospective* or volunteer*).ti,ab. \\
\hline 34 & or/15-33 \\
\hline 35 & animals/ not humans/ \\
\hline 36 & 34 not 35 \\
\hline 37 & and $/ 10,36 \quad$ This row general cancer trials with patient navigation trials \\
\hline 38 & This row lung cancer patient navigation trials \\
\hline 39 & Meta-Analysis as Topic/ \\
\hline 40 & meta analy\$.tw. \\
\hline 41 & metaanaly\$.tw. \\
\hline 42 & Meta-Analysis/ \\
\hline 43 & (systematic adj (review $\$ 1$ or overview $\$ 1)$ ).tw. \\
\hline 44 & exp Review Literature as Topic/ \\
\hline 45 & or/39-44 \\
\hline 46 & cochrane.ab. \\
\hline 47 & embase.ab. \\
\hline 48 & (psychlit or psyclit).ab. \\
\hline 49 & (psychinfo or psycinfo).ab. \\
\hline 50 & (cinahl or cinhal).ab. \\
\hline 51 & science citation index.ab. \\
\hline 52 & bids.ab. \\
\hline 53 & cancerlit.ab. \\
\hline 54 & or/46-53 \\
\hline 55 & reference list\$.ab. \\
\hline 56 & bibliograph\$.ab. \\
\hline 57 & hand-search\$.ab. \\
\hline 58 & relevant journals.ab. \\
\hline 59 & manual search\$.ab. \\
\hline 60 & or/55-59 \\
\hline 61 & selection criteria.ab. \\
\hline 62 & data extraction.ab. \\
\hline 63 & 61 or 62 \\
\hline 64 & Review/ \\
\hline 65 & 63 and 64 \\
\hline 66 & Comment/ \\
\hline 67 & Letter/ \\
\hline 68 & Editorial/ \\
\hline 69 & animal/ \\
\hline 70 & human/ \\
\hline 71 & 69 not (69 and 70) \\
\hline
\end{tabular}




\begin{tabular}{|c|ll|}
\hline$\#$ & Searches \\
\hline 72 & or/66-68,71 \\
\hline 73 & 45 or 54 or 60 or 65 \\
\hline 74 & 73 not 72 & \\
\hline 75 & and $/ 10,74$ & This row general cancer patient navigation systematic reviews/meta-analyses \\
\hline 76 & and $/ 11,74$ & This row lung cancer patient navigation systematic reviews/meta-analyses \\
\hline
\end{tabular}

\section{CINAHL(EBSCOhost)}

Date searched: July 27, 2018

Searched by: Information Specialist

\begin{tabular}{|c|c|c|}
\hline Concept & $\begin{array}{l}\text { Controlled Vocabulary } \\
\text { Terms }\end{array}$ & Free Search Terms \\
\hline \multicolumn{3}{|l|}{$\begin{array}{l}\text { Search for Trials of Patient } \\
\text { Navigation for Lung Cancer }\end{array}$} \\
\hline \multirow[t]{2}{*}{ Patient Navigation } & $\begin{array}{l}\text { (MH "Patient Navigation") } \\
\text { OR }\end{array}$ & $\begin{array}{l}\text { (TI ( navigation OR navigator OR navigators ) OR } \\
\text { AB ( navigation OR navigator OR navigators ) } \\
\text { AND } \\
\text { TI ( lay or layperson or nurse* or patient* or peer* } \\
\text { or "social work*" or volunteer* }) \text { OR AB ( lay or } \\
\text { layperson or nurse* or patient* or peer* or "social } \\
\text { work*" or volunteer*)) } \\
\text { NOT } \\
\text { electromagnetic OR tomography OR } \\
\text { bronchoscopic }\end{array}$ \\
\hline & AND & \\
\hline Lung Cancer & $\begin{array}{l}\text { (MH "Lung Neoplasms+") OR } \\
\text { (MH "Carcinoma, Non-Small- } \\
\text { Cell Lung") } \\
\text { OR }\end{array}$ & $\begin{array}{l}\text { (TI ( cancer OR carcinoma OR neoplasm ) OR AB } \\
\text { ( cancer OR carcinoma OR neoplasm ) } \\
\text { AND } \\
\text { ( lung OR pulmonary OR bronchial ) OR AB ( lung } \\
\text { OR pulmonary OR bronchial )) }\end{array}$ \\
\hline Limits: & & $\begin{array}{l}\text { Published Date: } 20140101-20181231 \text { [2014 to } \\
\text { present] } \\
\text { AND } \\
\text { Source Type = "Academic Journals" }\end{array}$ \\
\hline $\begin{array}{l}\text { Search for General Models } \\
\text { for Patient Navigation in } \\
\text { Cancer. }\end{array}$ & & \\
\hline
\end{tabular}




\begin{tabular}{|c|c|c|}
\hline Concept & $\begin{array}{l}\text { Controlled Vocabulary } \\
\text { Terms }\end{array}$ & Free Search Terms \\
\hline \multirow[t]{2}{*}{ Patient Navigation } & $\begin{array}{l}\text { (MH "Patient Navigation") } \\
\text { OR }\end{array}$ & $\begin{array}{l}\text { (TI ( navigation OR navigator OR navigators ) OR } \\
\text { AB ( navigation OR navigator OR navigators ) } \\
\text { AND } \\
\text { TI ( lay or layperson or nurse* or patient* or peer* } \\
\text { or "social work*" or volunteer* } \text { ) OR AB ( lay or } \\
\text { layperson or nurse* or patient* or peer* or "social } \\
\text { work*" or volunteer*)) } \\
\text { NOT } \\
\text { electromagnetic OR tomography OR } \\
\text { bronchoscopic }\end{array}$ \\
\hline & AND & \\
\hline \multirow[t]{2}{*}{ Cancer in General } & $\begin{array}{l}\text { ((MH "Carcinoma") } \\
\text { OR } \\
\text { (MH "Neoplasms+") } \\
\text { OR } \\
\text { (MH "Cancer Survivors") OR } \\
\text { (MH "Cancer Screening") OR } \\
\text { (MH "Cancer Care Facilities")) } \\
\text { OR }\end{array}$ & $\begin{array}{l}\text { ( ( carcinoma OR neoplasm OR cancer ) OR AB ( } \\
\text { carcinoma OR neoplasm OR cancer )) }\end{array}$ \\
\hline & AND & \\
\hline Models & $\begin{array}{l}\text { ((MH "Classification") } \\
\text { OR } \\
\text { (MH "Conceptual } \\
\text { Framework") } \\
\text { OR } \\
\text { (MH "Theory+")) } \\
\text { OR }\end{array}$ & $\begin{array}{l}\text { (TI ( taxonomy OR classification OR theory OR } \\
\text { model OR conceptualization OR framework ) OR } \\
\text { AB ( taxonomy OR classification OR theory OR } \\
\text { model OR conceptualization OR framework )) }\end{array}$ \\
\hline Limits & $\begin{array}{l}\text { Published Date: } 20140101- \\
20181231 \text { [2014 to present] } \\
\text { AND } \\
\text { Source Type = "Academic } \\
\text { Journals" }\end{array}$ & \\
\hline
\end{tabular}

